\title{
Seeing Experimental Imperialism in the Nuclear Pacific
}

\author{
Kevin Hamilton ${ }^{a}$, Ned O'Gorman b \\ Keywords: nuclear, sovereignty, colonialism, imperialism, photography \\ https://doi.org/10.1525/001c.18496
}

\begin{abstract}
Those looking to judge the historical wrongs of American nuclear testing often discover an overwhelming surplus of images that amount to a series of incoherent visual fragments, leaving us with an abundant historical record and barriers to interpreting that record. This essay meets this challenge through discerning a new role for photography in the bombing of the Marshall Islands. In revisiting the function of the camera in the staging of these nuclear experiments, we find a model for the United States' larger relationship to the post-WWII Pacific. Through a process we call "experimental imperialism," U.S. nuclear tests utilized both cameras and international law to render living beings and the spaces they inhabited as lab-like specimens.
\end{abstract}

Images and media from disasters of settler colonialism and climate change displacement tend to proliferate; the violent acts they depict often take place in plain sight, well documented and circulated. Those seeking reparation and repair thus face challenges more in parsing the evidence to make it speak and less in uncovering secrets or conspiracies. In this essay, we account for this surplus of visible evidence in the case of US nuclear testing programs and observe a larger structure at work relevant to other disaster media as well. Namely, we take up the bombing of the lands and waters of the Marshall Islands as exemplary of "experimental imperialism," wherein empire forgoes annexation and extraction, employing instead strategies of isolation and enclosure. At the scale of a sea, an atoll, or a single living body, experimental imperialism isolates to create predictable and controllable systems that produce data and knowledge as their raw material—often, but not always, in the form of images.

These disaster media, often made inscrutable by sheer quantity, also support frequent misrepresentation of Indigenous struggle as foreclosed, disappeared, and lost to inevitable decline. Even as Indigenous activists, scholars, and artists mobilize these images as evidence in living struggles for reparation, we need to also see disaster media as playing a role in the construction of sovereignty itself. In our article, we apply the frame of experimental imperialism to interpret

\footnotetext{
a Kevin Hamilton is an artist, scholar, and administrator based at the University of Illinois, Urbana-Champaign, where has served on faculty since 2002, and as Dean of the College of Fine and Applied Arts since 2018. His book with Ned O'Gorman, Lookout America! The Secret Hollywood Studio at the Heart of the Cold War (Dartmouth, 2018) reflects over a decade of archival research, media production, presentation, and publication on the role of photography and film in America's rise to nuclear supremacy. Previous work includes early published research on the ethics of algorithmic media production and consumption, and artworks exploring histories of race, space, and science. Kevin also advises multiple efforts in support of multi-modal and interdisciplinary scholarship, including service as co-founder of Ground Works, an online peer-reviewed platform for interdisciplinary arts-inclusive research.

b Ned O'Gorman is University Scholar and Professor of Communication at the University of Illinois. He writes at the intersections of Cold War history, media criticism, and political theory. He is author, most recently, of Politics for Everybody: Reading Hannah Arendt in Uncertain Times (Chicago), and - with Kevin Hamilton - Lookout America! The Secret Hollywood Film Studio at the Heart of the Cold War (Dartmouth).
} 
one such inscrutable artifact - a rare photo album from a nuclear test-in order to illuminate the function of the test and its media in the structuring of sovereignty.

In addressing the role of disaster media in representations of the Marshall Islands, we of course also face at least two disasters: those of the nuclear tests and of climate change. Many mark the beginning of the Anthropocene at the beginning of nuclear testing. The detonation of nuclear devices and weapons, the argument holds, inaugurated a geologic period of unprecedented human influence on the planet (cited as the cause of flooding and disappearance of the Marshall Islands today). However, as Kathryn Yusoff argues, the temporal framing of the Anthropocene obscures the social nature of geology and geography from earlier time periods when science reorganized the planet, delineating the human from the inhuman in the service of slavery and other industries of imperial extraction (2018). Similarly, we situate the figure of disappearing islands in the Pacific today as the latest point in a genealogy that begins with settler colonial occupation and runs through the atomic testing era. Experimental imperialism helps us see in seasons of successive violence against places and people less a story of empire's expansion and success than an evolution of how empires draw from structures of seeing and feeling to perform and enact sovereignty. As in contemporary narratives of disappearing glaciers, photographic depictions of flooded islands may reflect evidence-based realities of global warming, but they also rely on a depiction that places the islands outside of time and space-expendable, marginal, and manageable (N. A. Brown 2014; Farbotko 2010). As also evidenced in early settler photography of "disappearing Indians," images of "nature in crisis" at humanity's hand serve complex functions within a larger rhetoric of "salvage" that positions the sovereign as uniquely able to manage life and death (N. A. Brown 2013).

We see in nuclear test photography a key innovation not in empire's inevitable expansion and reign over the planet but in a history of imperial responses to struggles over sovereignty. Some might see in the sheer volume of nuclear test documentation evidence of a violence concluded and recorded in forensic detail. We instead see the accumulated products of an ongoing process that many continue to contest. It took our encounter with a rare instance of nuclear photography that refuses identification as data to see this clearly. In the context of Operation Greenhouse, a penultimate experiment leading up to the world's first hydrogen bomb, an ephemeral photo album of unknown provenance and scant historical details provides a window into media's role in not only the division of the world into the human and the inhuman (Yusoff) but the deadly reconfiguration of living beings as sensors in a closed system-a system that enacts a position for the sovereign outside time and space by locking subjects into irrevocably historical and marginal positions in time and space. Understanding this innovation in imperial representation is key to reimagining these relationships at the site of struggle and to guarding against approaches to environmental justice that leave empire's sensoria unexamined. 


\section{Experimental Imperialism}

What is the work of images in judging historical wrongs? In her book Potential History, Ariella Aïsha Azoulay (2019) argues that photography, in origin and in ontology, is "rooted in imperial formations of power" (3). Photography assumes-or we might say presumes-that objects "are waiting to be reproduced" (4). Before the shutter ever moves, the scene is prefigured as fit for the "petty sovereign" of the stand-alone photograph:

The petty sovereign asserts itself at that moment as preceding and separate from the photographic event, from the participants, and from the situation out of which a photograph is about to be extracted. It commands what sort of things have to be distanced, bracketed, removed, forgotten, suppressed, ignored, overcome, and made irrelevant for the shutter of the camera to function, as well as for a photograph to be taken and its meaning accepted. (2)

The "imperial" character of the photographic shutter is not a mere characterization-or, as Azoulay writes, it is "not a metaphor for the operation of imperial power, but it is a later materialization of an imperial technology" (6-7). Throughout her book, Azoulay shows how photography has been incorporated into modes of accumulation, exploitation, and destruction, and how-even before the advent of photography-imperial lords dreamed up means of image extraction that portended the invention of photography.

Thus, the photographic extraction can act as a form of sovereign judgment. Consider the image of the mushroom cloud over Nagasaki (figure 1). It excludes from view its frail and fraught history of production, just as sovereignty hides from view its precarious invention through rhetoric and representation across empire's bureaucratic, economic, and social domains. It conceals even the target, when the target, as Rey Chow (2006) has argued, is precisely its epochal significance.

In 1945, toward the end of the Second World War, the United States dropped its entire inventory of two atomic bombs on Japan. What politics of vision-of viewing the world-accompanied the strategic decision to drop the bomb? The technologies of atomic warfare, inseparable from those of seeing, have far-reaching ramifications. Following Heidegger's suggestion that in modernity the world has come to be grasped and conceived as "a picture," we may say that in the wake of the atomic bombs the world has come to be grasped and conceived as a target. (12, emphasis added)

Still, what the photograph from above Nagasaki features is not the world as target but only the excessive output of a sovereign input of casing, wires, explosives, and plutonium. Thus, it extracts only what it inserts; sees only the 


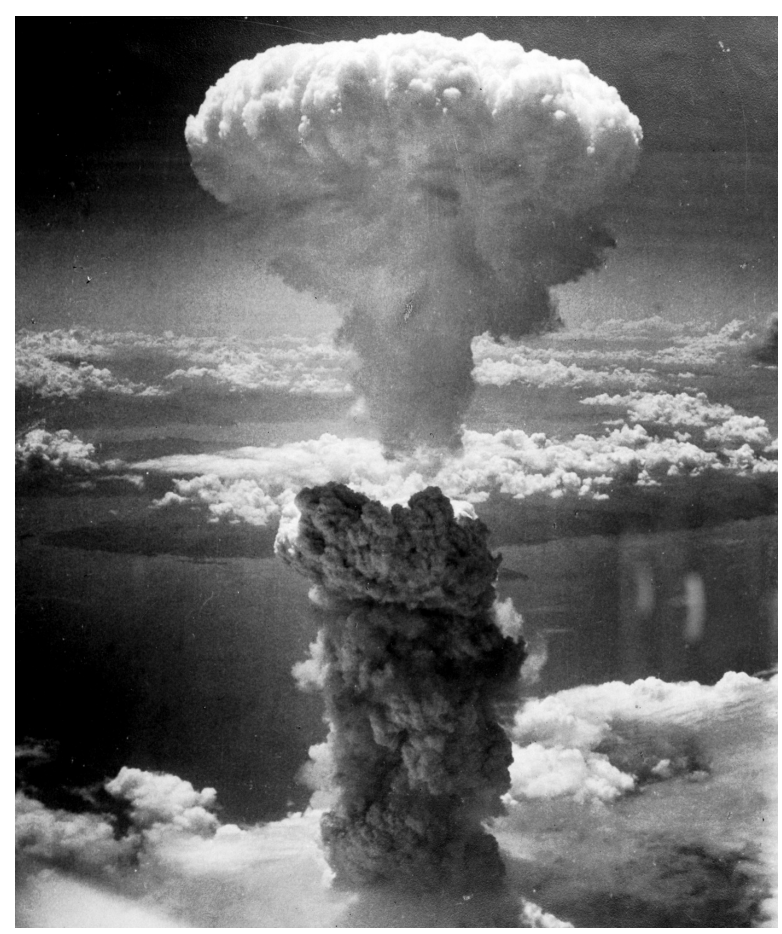

Figure 1: Atomic cloud rises over Nagasaki, Japan, 9 August 1945.

Image courtesy of the National Archives, RG 208: Records of the Office of War Information, 1926-1951.

product of what it puts in. In the photograph, the skies above Nagasaki are made the mirror of a sovereign judgment, a reflection that hides every detail that might disturb or otherwise dispute that judgment.

This is experimental imperialism. Rooted in the dream-itself sovereign in origin, as Thomas Hobbes's Leviathan attests-of constructing a perfectly closed system of action and reaction, experimental imperialism is predicated neither on an insane appetite for expansion nor on the theft of resources (cf. Arendt 1976, 123-47). As we will show, the United States isolates the Marshall Islands not to annex them through a form of primitive accumulation through dispossession or to claim them in the production of surplus (cf. Harvey 2004). Rather, experimental imperialism depends on the fiction of constriction-of "enclosure" - and the insertion of inputs to achieve outputs. This form of sovereign judgment extracts only that which it installs, presuming that the only thing of "value" in its field is what it constructs. Though in our examples, experimental imperialism leaves behind ample evidence of violence in the form of images and radiation contamination, enclosure serves to place all this evidence in the service of extracting information that validates and even strengthens imperial subjectivity and sovereignty. In harnessing living worlds as closed systems in the production of information, the sovereign both mobilizes that information in the production of value and secures its position outside the world, and therefore outside moral judgment. 
We see an early glimpse of this new regime in the decision to bomb Nagasaki. As Evan Thomas reports, "If there was little debate over the moral rights and wrongs of atomizing Hiroshima, there was even less over Nagasaki; indeed, no debate at all. The operation was left to [General Leslie R.] Groves, who was eager to show that an implosion bomb, which costs $\$ 400$ million to develop, could work as well as the trigger-type bomb that had destroyed Hiroshima" (qtd. in Chow 2006, 28). Though many take care to distinguish the bombings of Nagasaki and Hiroshima from the tests conducted before and after those wartime detonations, both functioned to inaugurate a key component of nuclear testing programs - the evaluation of radiation's effect on human life. So though images are more scarce of these two detonations, other data from the tests exist in abundance. Even President Truman, sharing news of the bombing aboard the USS Augusta as he returned home from the Potsdam Conference, announced that "The experiment has been an overwhelming success" ("He's Steady Under Fire” 1945).

\section{Insubstantial Evidence: Images That Fail to Incriminate}

In the case of America's postwar nuclear testing program, particularly in the waters of what European explorers long ago came to call the "Pacific," decades of photographs have been produced and reproduced as the image outputs of sovereign experiments. As we have argued elsewhere, the endless reproduction of these "mushroom-cloud" images has rendered them at once iconic-indexes of "a general condition rather than a specific event" (Hariman and Lucaites 2012, 142) - and mute, at least with regard to their particular devastations (Hamilton and O'Gorman 2018, 229-49). Who can tell the difference between the photograph of devastation being wrought upon Enewetak Atoll in 1952 by the Ivy Mike thermonuclear blast and that done to Bikini Atoll's land and waters in 1954 by the Castle Bravo thermonuclear detonation (figure 2)? Only those who have trained their eyes to see the particulars in this general condition-only, that is, "specialists." Even as the atolls' historic inhabitants experience the differences between tests all too keenly through forced migration, health devastation, and destruction of sacred sites, the official image record affords such identification only to the experts.

Nuclear tests have destroyed people's land, water, air, and their very lives, but their repeated photographic seizure has threatened to take something just as precious but still harder to measure: the capacity to harness sensation and feeling in support of forensic, not to mention political, judgment (Arendt 1982). Hidden in the etymology of the word "numb" is nim, "to take." To be sure, there are many other, less familiar images of nuclear-weapons exercises in the Pacific than the mushroom cloud. A report (Clarkson 1954) written in 1954 by the commander of the USS Philip, the naval vessel that belatedly evacuated Marshallese from the toxic fallout of the Castle Bravo detonation, describes "motion picture and still photography ... accomplished on various phases of the initial pre-evacuation surveys and on the reception of natives at Kwajalein." The commander wished to assure his superiors that there was 

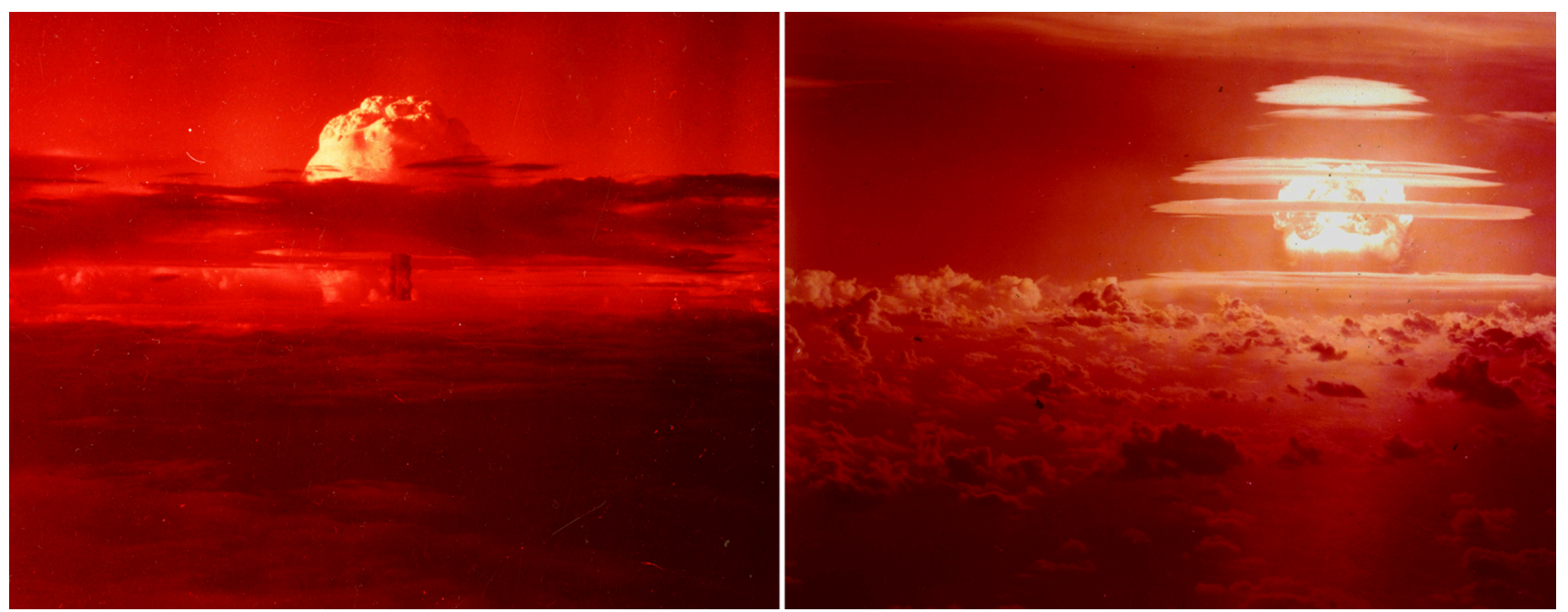

Figure 2: Mushroom clouds from the Ivy Mike, 1952 (left), and Castle Bravo, 1954 (right), thermonuclear blasts.

Images courtesy of the National Archives, RG 374: Records of the Defense Threat Reduction Agency, 1943-2005.

indeed "over-all photographic coverage." Many of these images are now forever lost (poor archiving practices, impenetrable secrecy regimes, or simple rot and decay). The others, when they surface-as they occasionally do in official repositories, local archives, and, as we will discuss, auctions-almost always appear devoid of the testimony and witnesses they need to help them tell their particular tales. They, too, have been folded into the general nuclear condition.

Recently, another general condition, climate crisis, has again turned attention to the nuclear-damaged atolls and waters of the Pacific. Using techniques based in part on the US government's fallout measuring techniques-particularly as they were developed after the 1954 Castle Bravo blast-climate scientists measure carbon movements through the atmosphere, the oceans, and the ecosphere. Such work, as Paul Edwards writes, has been "crucial to understanding anthropogenic climate change" (Edwards 2012, 29; see also Masco 2015) (even as other scholars have questioned this framing of time and geology-cf. Yusoff 2018). But climate scientists not only measure carbon but also gauge rising sea levels. Thus, the waters and lands that once featured prominently in press coverage of nuclear tests are again in the public eye. And rising seas pose new threats to nuclear waste storage sites in the Marshall Islands, as one general condition confounds another.

In one prominent example, a Los Angeles Times feature took readers to the Marshall Islands in a seven-article series that documented not only rising sea levels but also "extensive coral bleaching, fish kills and algae blooms-as well as major disease outbreaks, including the nation's largest recorded epidemic of dengue fever" (Rust 2019). Military documentaries once treated midtwentieth-century viewers to airborne perspectives of the isolated islands of the Marshallese; now reporters capture imagery of the poisoned spaces of the 
Marshall Islands from drones. The same maps of blue waters and brown island rings that now pass through our web browsers appeared in print a half century ago in picture magazines like LIFE.

The Los Angeles Times series asks the questions that the inhabitants of these waters have been asking for decades: how did this particular crisis happen, and how will it be made right again? Scientists, journalists, and activists once again take radiation measurements and pore over medical records, court documents, and diplomatic communications. We see in this wave of renewed attention to the Marshall Islands the familiar forensic tools common in the prosecution of state crimes. As in the investigation of human rights abuses in Central and South America, or in the public litigation of American slavery and Native American genocide, the Marshallese and their advocates reach to not only tell their story but also reconstruct the imperial crime. With the promise of exposure brings a demand for justice. The new spike in attention for the Marshall Islands in light of its role as a "canary in the coal mine" for global warming and as a site for the "golden spike" of measuring Anthropocenic time might at first invite hope in the power of visual evidence to effect judgment of historical wrongs. Some may even see in this new chapter some promise of reclaiming the imperial shutter that Azoulay identifies and critiques. But as the land and seas themselves were never fully taken, there is no territory to cede, no extracted material to be returned. As a laboratory for experimental imperial production, the Marshall Islands performed their function without ever entering formal US possession; they remained independent while overseen as a trust territory. As we shall see, such enclosure without full dispossession or annexation is key to experimental imperialism's power.

\section{Conquest through Enclosure: Extraction without Annexation}

Indeed, long before the Cold War, the history of US-Marshallese relations was more complex than the tag "imperial" might at first suggest. The waters and islands of what is called Micronesia, a region of Oceania, are comprised of some 680 square miles, or 1,800 square kilometers (Louis 1972, xiii). If superimposed on a map of Europe, it would stretch from London to Tehran (Wuerch and Ballendorf 1994, ix). In the nineteenth century, Micronesia was a major site for US and European whaling industries. At the turn of the century, the vast seascape became a colonial prize contested between Spain and Germany, with Germany winning possession in 1899, a consequence of Spain's defeat in the Spanish-American War. Japan captured the islands in World War I, after which they were formally bestowed on the Empire of Japan by the League of Nations as a "mandate" (Wuerch and Ballendorf 1994, xi). Japan invested heavily in the area, turning it into a major region for sugar cultivation and refining, and bringing thousands of Japanese to settle in the area (Wuerch and Ballendorf 1994, xi). But in 1935 the Japanese Empire withdrew from the League of Nations and began to fortify the area for war (Wuerch and 
Ballendorf 1994, xii). This began an especially dark time for Marshallese, one that would cause many of them to celebrate the arrival of American military forces during World War II (Friedman 1997, 51).

Importantly, the Marshall Islands were largely excluded from another kind of imperial science during the first half of the twentieth century: anthropology. Bronislaw Malinowski remained far south of the area in the Trobriand Islands, next to Papua New Guinea. Margaret Mead spent time in Samoa, Gregory Bateson in New Guinea, Raymond Firth in the Solomon Islands-all more than a thousand miles away from the Marshall Islands. In the first fifteen volumes (1932-45) of the anthropological journal Oceania, in which Mead, Bateson, and Firth all published, not a single article concerns fieldwork among the Marshallese-out of more than 250 studies. ${ }^{1}$ The journal was dominated instead by research on the aboriginal peoples of northern Australia, New Zealand, and Melanesia, the seas and lands where the structures of European, as opposed to Japanese, colonization still held. If one looks at a map of nuclear tests in the Pacific, the radioactive events there form a kind of distant perimeter around the hotbeds of Anglo-American anthropological research-as if to have become the scientific subject of the white, English-speaking anthropological gaze was enough to have saved one's home from nuclear fire and fallout.

After World War II, the Marshall Islands area was quickly identified as strategically valuable for the maintenance of American hegemony, essential not just for keeping Japan docile but, even more importantly, for containing the Soviet Union. American military commanders quickly expelled all Japanese nationals from the Marshall Islands, while American diplomats worked in the United Nations to designate the Marshalls and Micronesia a US-administered "trust territory," as allowed by Article 75 of the United Nations Charter. Like the League of Nations mandate system, the UN "trust system" situated traditional colonial structures within a set of international regulations. The UN trust system called upon occupying powers to promote the "political, economic, social, and educational advancement of the inhabitants of the trust territories, and their progressive development towards self-government or independence" (United Nations 1945, Article 76). Such was the discourse of "development" that the United States made part of the global UN mission (O’Gorman 2011, 140).

But "development" would be stolen from the Marshallese with their land, seas, livelihoods, and lives: while some postwar American diplomats and military commanders did indeed argue for economic and political development in the area, a chorus of others argued that its chief and only value to the United States was for national security. Hence, the United States invoked Article 82 of the

\footnotetext{
1 The closest the journal got was an article published by Camilla H. Wedgwood in 1942, "Notes on the Marshall Islands" (Wedgwood 1942). The piece was based on an interview with a woman from the Marshall Islands named Lenina, an "informant" Wedgwood met while doing fieldwork on Nauru Island in 1935.
} 
UN Charter and got the Pacific Trust Territory designated a "strategic" area. To date, Article 82 has been granted only once-against the Marshallese. It allowed the United States to prioritize security interests over the "progressive development" of the peoples of the Marshalls and Micronesia. That is, it allowed the United States to turn the Marshall Islands and Micronesia into a nuclear bombing zone.

\section{The Pacific as Information Producer: The Data Overwhelms}

In the case of the 105 nuclear tests that would take place in the strategic trust territory, the reconstruction of American imperial crimes faces challenges far beyond the usual barriers presented by state secrecy or obfuscation. The United States, like England and France-which also aggressively nuclear-bombed the Pacific - relied on immense operations involving thousands upon thousands of laborers and the mobilization of resources and logistics at a truly planetary scale. These operations left behind traces and records at the upper reach of the human capacity for processing and understanding.

They include what one geologist (Higley 2020) described to us as an anthropogenic "soil horizon." While doing paleoclimatology research on Christmas Island, or Kiritimati (which sits outside of the Pacific Trust Territory but within the fold of US and British nuclear testing during the 1950s and 1960s), Melissa Higley found a change in color in the layers of the dunes in several locations. The plant material from those layers dated to 1957, plus or minus two years - that is, the period of British nuclear tests in the area, when more than three thousand servicemen were on Christmas Island. Higley found that this nuclear activity fundamentally changed the sand structure of the island and left, not unlike a photograph, a pattern of color markings on rock and mineral particles on a suprahuman scale. Though such a change might be sampled, it cannot be fully known by a researcher without an islandsized infrastructure to match-a map to match the territory.

The scale of the imagery on film produced by these tests is itself evidence of this challenge to representation and interpretation. For example, we do not know how many hours of film footage resulted from Operation Crossroads at Bikini Atoll, the first postwar Pacific nuclear tests, detonating America's fourth nuclear bomb. But we know it was a great deal. Jonathan Weisgall (1994) writes that there were more than 700 cameras used, with more than five hundred photographers on the job. A full 324 of the cameras were airborne, aboard planes. Together these images produced well over a million images in just the first few seconds of the first of Crossroads' two blasts. Estimates hold that well over half the world's film supply was there at Bikini for these purposes. Indeed, one report ("Army Air Forces Operation Crossroads" 1946) described the nuclear test as "primarily photographic."

This surplus of imaging set in motion decades of media circulation, with the same images serving scientific analysis, propaganda, journalism, and appropriation in art and popular culture. Indeed, Crossroads would set a 
photographic benchmark for subsequent Pacific nuclear tests. Lookout Mountain Laboratory, the Air Force film studio responsible for documentary photography of American nuclear tests from 1948 to the mid-1960s, housed a warehouse full of still photos and motion-picture reels of American nuclear operations (Hamilton and O'Gorman 2018). This film was used for far more than documentation and propaganda. High-speed photography was used to measure the yields of nuclear bombs (Hamilton and O'Gorman 2018, 41-42). Indeed, it was the most reliable means of such measurement. Scientists would measure, frame by frame, the scope and rate of change in the growth of fireballs. Today, scientists and technicians at Lawrence Livermore National Laboratory are digitizing and using computers to reanalyze the most technical of these photos and films-at least those they can get ahold of - and have found that original measurements were off, sometimes woefully off, due to human visual error. Hence, they are engaged in a nationwide quest to gather as much of the original film as possible, as well as the cameras used to shoot it, so as to get the scientific story right. ${ }^{2}$ Here, again, it is experts who are attending to the particulars of the nuclear condition, while the rest of us are left in a general state.

\section{A Rare Promise of Revelation: Inscrutability Even at the Heart of Empire}

Amid the sheer scale and range of these photographic records, important and rare items do surface, but often with little contextualizing information. For example, a possibly one-of-a-kind photo album for Operation Greenhouse, an American nuclear test series carried out in 1951, recently surfaced for auction by a London-based purveyor of "rare science books dating from the late Middle Ages to the 20th century," priced for collectors at $£ 6,500$ (figure 3). Produced and assembled by hand, this album in many ways resembles a tourist's scrapbook, with prints likely created from original negatives, mounted within decorative borders on large archival pages. Many of the images appear unique. The public surfacing of this album decades after the test thus promised new information about what took place at a secretive and historic operation in the United States' march toward nuclear supremacy.

Thankfully, our institution's library was able to acquire this album for study and preservation, allowing a level of scrutiny and access that many a private collector of militaria would never allow. On closer examination and even acquisition, this object revealed little further information or provenance, however. Carefully printed photographs clearly taken from within the cone of secrecy each command their own page, hand mounted with care-and yet with no captions; no narrative text; no identification of the photographer, those depicted, or the audience. That such a precious object might originate at the heart of state secrecy while divulging so little cast us back on the problem 

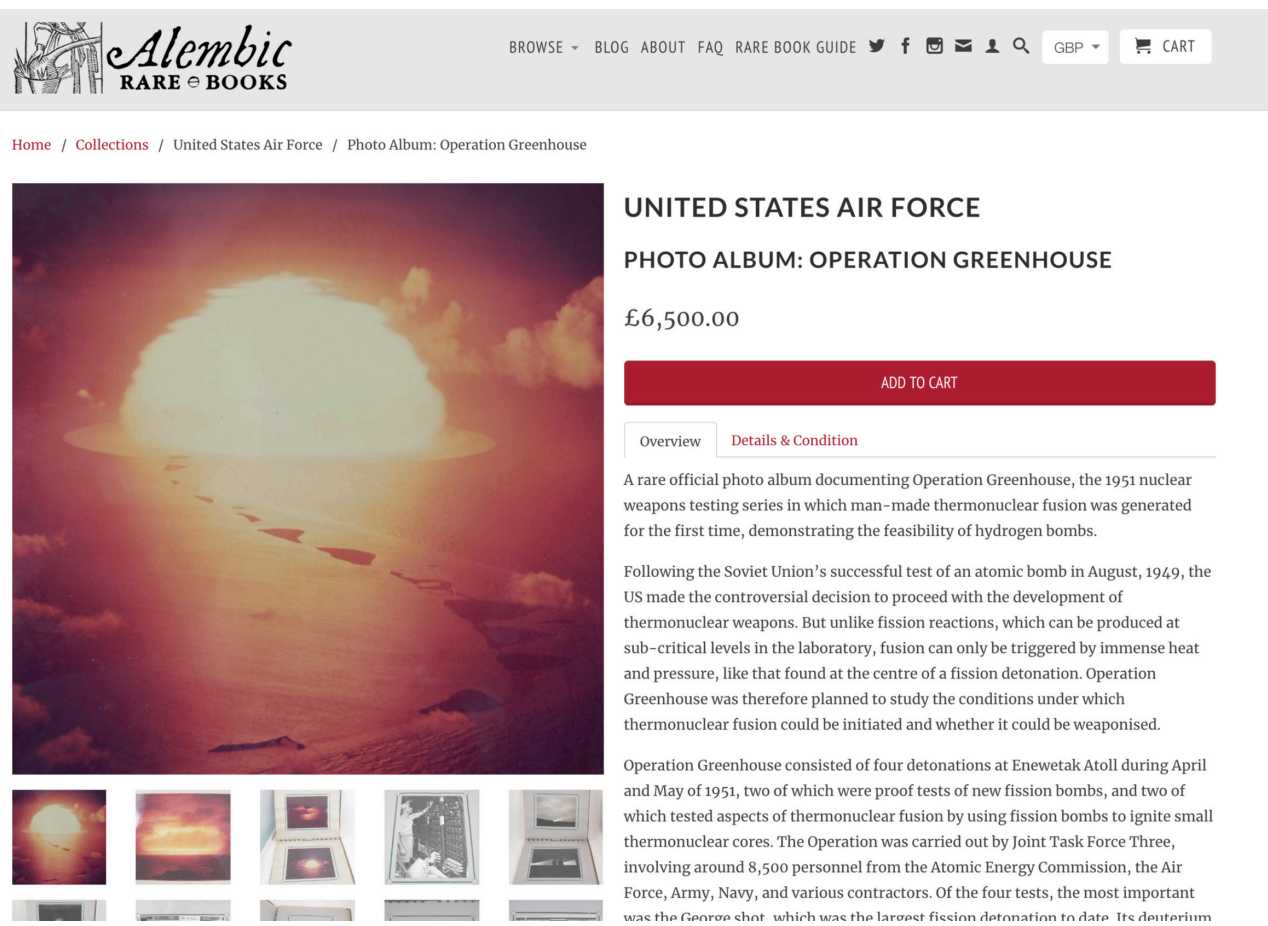

Figure 3: Screenshot of online auction for Operation Greenhouse photo album, 2018.

Image courtesy of the authors.

of photographic surplus in nuclear tests. The album forced us to ask how evidence of ecological violence serves other than forensic ends in accounting for historical wrongs. We had to look for other ways to let this newly surfaced record inform and form understanding. The album has much to teach us about photography's function within the closed system of an experimental imperial sensorium.

Greenhouse was the fifth American postwar nuclear test series and the third conducted in the waters of the Pacific. To hold this photo album is to peer into the vestiges of a highly complex organization that was not only eminently capable of detailed archiving but dependent on densely detailed plans that spanned half the globe over many months. These plans play out across hundreds of documents, photographs, and films made public in the 1990s, largely to support the legal cases of irradiated test workers. Yet among this proliferation of organizational records, this album is distinctive for both the images it contains, many of which we have seen in no other archives, and its mode of presentation.

Around Enewetak Atoll some seventy years ago, light radiated through lenses and onto negative film; several darkroom sessions later, the images seized appeared on paper and were carefully placed in a scrapbook. Yet the album itself carries almost no words. From the title page (figure 4), we can see which test the book commemorates and the origin of the book at Lookout Mountain Laboratory. Pages of black-and-white prints follow, mixing portraits of smiling uniformed men with candid shots of other men engaged in obscure activities 


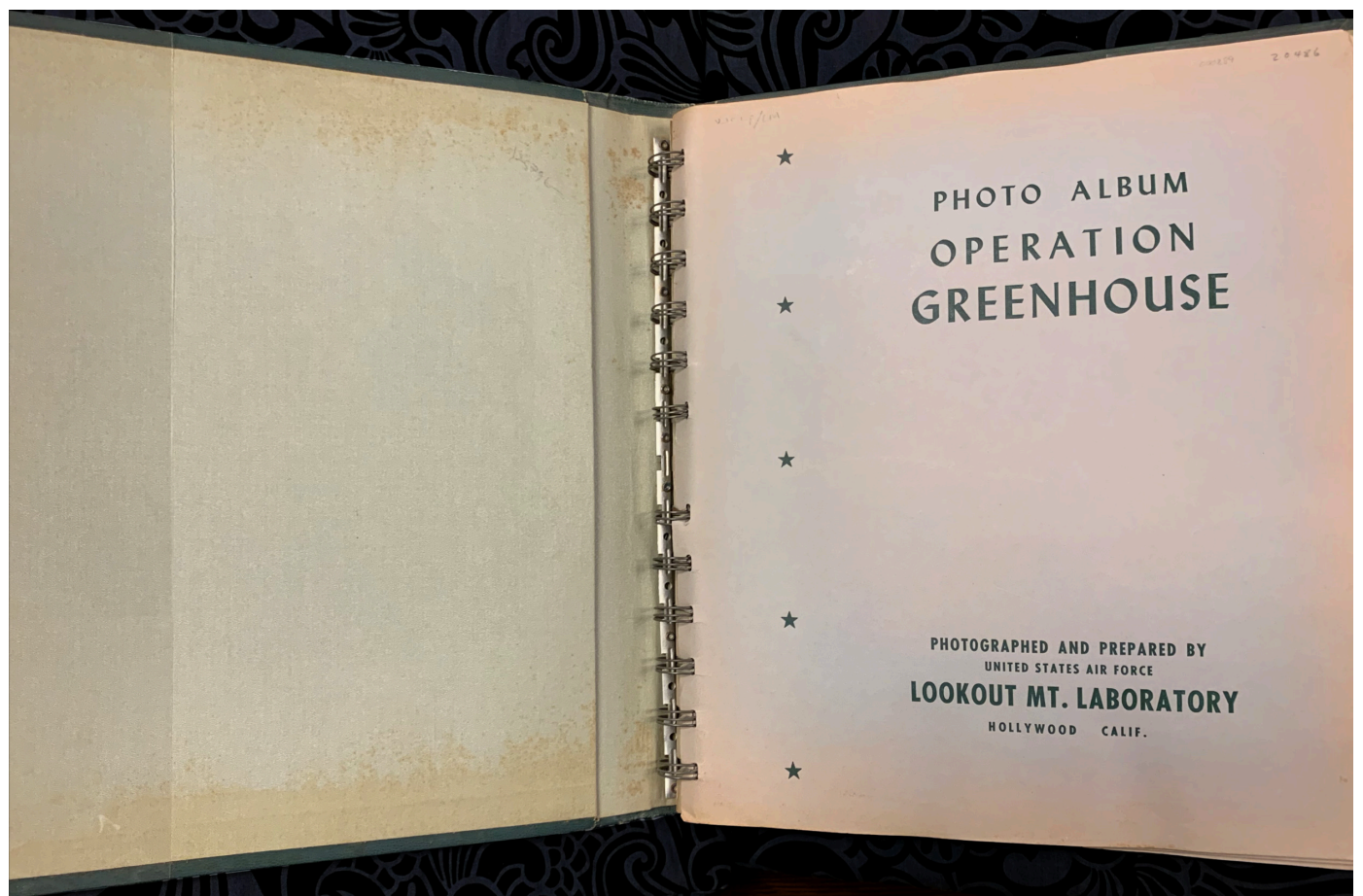

Figure 4: Title page from Operation Greenhouse photo album, 1951.

Image courtesy of the Rare Book \& Manuscript Library, University of Illinois at Urbana-Champaign.

on beaches and in labs. Sunset photographs and recreational shots that would be at home in any tourist album follow careful documentation of military planes and unnameable machines and equipment. Striking pairs ring out: in one spread, an image of a young Marshallese woman in traditional dress, barechested, faces an image of a white man in shorts, examining a wall of pinup centerfolds. The only implied narrative in the album's sequence of images, more than seventy pages in length, lies in the final few images, wherein color prints of fireballs and mushroom clouds signal a reason for being (figure 5).

We can confidently surmise that between the album's rarefied nature and its heavy reliance on portraits and snapshots of executive leaders, it likely belonged to one of the test operation's key commanders. Yet without captions or time stamps, we cannot specify the particular activities, figures, or sites depicted. Before finding this album, the disaster of the Greenhouse test already defied judgment by means of the sheer scale of available data and images. The emergence of such a privileged and distinctive document as this photo album might first suggest a possible key to the rest, something analogous to the Guatemalan National Police Historical Archives, which helps make sense of the disappeared in that state's history of violence. However, without identifying information, this album's images stand mute with respect to forensic judgment and recovery of past wrongs. If an object like this is to help us in telling the story of how the Marshall Islands became a nuclear wasteland, we will have to take a different approach—one that can account for this album's place within an overwhelming excess of information, an archive that, like the rationales for the tests themselves, challenges sense. 


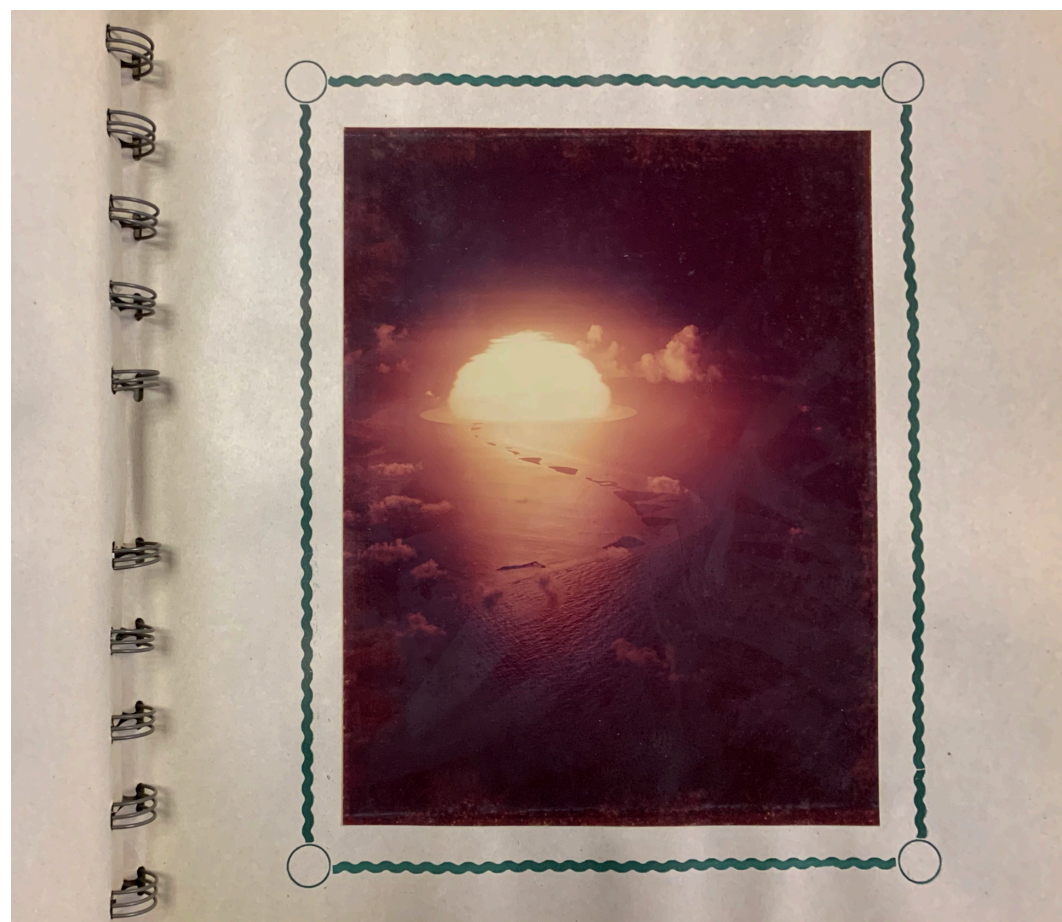

Figure 5: Concluding page from Operation Greenhouse photo album, 1951.

Image courtesy of the Rare Book \& Manuscript Library, University of Illinois at Urbana-Champaign.

\section{Colonial Enclosure as Closed System}

Elizabeth DeLoughrey (2009) describes the surplus of images generated by these tests as "hyper-visuality," building on both Paul Virilio's vision of wars fought over images as much as land and Teresia Teaiwa's analysis of photography's role in the colonial framing of Oceanic islands as isolable, substitutable, and therefore disposable. Where such "overrepresentation" of a place helps to reframe conquest, the imperial imaginary of Borges (1999) comes to mind, dissatisfied with all maps until one matches the size of the territory.

Just as important to understanding the role of images in Pacific nuclear tests, however, is how they help reframe atolls as "closed systems" of circulating water and life. DeLoughrey $(2013,168)$ also discusses how aerial depictions of the atolls helped frame them as not only replaceable in their isolation but also ecologically self-contained. Understood by some as closed systems of currents, flora, and fauna, atolls were converted into laboratories of study, as if contaminants would surely remain within the system, and available for careful examination. Aerial photography enforced this view through the depiction of the atolls from high above, obscuring their interconnections beneath the sea. Emerging oceanographic and ecological science also confirmed this view, mapping currents within the lagoons as self-contained.

Though official reports and documentaries about all the Pacific tests bear out such a reading, it is notable that Operation Greenhouse, in its very name, also suggests a closed system, a structure constructed for the isolated study of life. 
The Air Force film documentary produced by Lookout Mountain Laboratory, Operation Greenhouse (1952), describes Enewetak Atoll as a "giant lab in the middle of the ocean," comprising "individual islands spaced like beads on a necklace." Largely a story of the scientific experiments carried out during the test, the film also describes the military operation as a "self-contained unit" and the need for continued testing as "self-evident." Hence, we are indeed dealing with experimental imperialism, a system of enclosure where the only significant outputs are derived directly from sovereign inputs.

Though today we may recognize such talk of closed systems as more than imperial-as, for example, a form of ecological thinking appropriate to the description of organisms and atolls-in the context of the Cold War, such language was the stuff of engineers, not ecologists, reinforced by the then recent emergence of information theory, and specifically the new "systems science" of cybernetics. From MIT to Bell Labs to the Pentagon, cybernetics caught on after World War II as a way of understanding all processes in terms of information processes. Influential cyberneticians such as Norbert Wiener offered a new way of seeing the world as comprised of living and artificial systems, dependent for their existence on feedback loops of information and control. The thriving system, for Wiener, exists in "homeostasis," a state of balance in which internal processes function predictably in response to new external influences and stimuli. Examined through the lens of cybernetics, any isolable entity - be it a person, an organization, or an atoll-could be examined as autonomous and self-regulating (Ashby 1962). Applied equally in science, organizational management, manufacturing, and even economic theory, Cold War cybernetics laid the groundwork for cognitive science and systems theory as much as ecological thought.

Important to our question about the forensic recovery of the particulars of these tests is the function of memory within cybernetic systems. Historian of science Geoffrey Bowker has described the cybernetic approach to life and systems as set against memory (Bowker 2005, 99). Within a world composed of self-regulating systems, allocation of energy to memory is inefficient. The ideal self-regulating system within cybernetic science is the system so finely tuned that it can take any input and achieve the needed output without calling on memory at all to determine which output is appropriate. For cybernetics, a system moves toward autonomy, a present without memory, by enclosing a world within a responsive system of information flow.

Atolls, of course, are not ecologically isolated from their environments but are part of multiple flows of water, volcanic land, and more. They are open. Still, nuclear testing on these atolls required an understanding of them as closed and isolated in order to justify their irradiation as having no significant effect on the rest of the planet. To approach them as self-contained within a systems-science framework required the pressing of all resident organisms into maximum efficiency, with no energy given over to memory or to futurity. 
Photography, to be sure, could defy the cybernetic erasure. Especially at Operation Crossroads (1946), it was used to capture images for appropriation outside of the closed experimental system, on behalf of "history," propaganda, or art (Atkinson 2011; Wees 1993, 32-47). But, beginning with the 1948 Operation Sandstone tests in the Pacific, such exogenous photographic ends were reintegrated into the closed systems of experimental imperialism (Hamilton and O'Gorman 2018, 79-86). The cameras were there; they were indeed everywhere. But they were there only to seize that which was being imported: operations, detonations, and devastations. Cameras functioned as sensors within a system in which the being-bombed atoll was only the experimental subject. Film registered light for the purposes not of storage but of information transmission. Within each nuclear experiment, everything must be seen because everything must become information. In fact, given that the radiation produced by these bombs is only a difference in degree from visible light, we should look at cameras and film as but one type of sensor in a whole network of sensing surfaces in the system of experimentation. Let us not forget the array of dosimeters, all those mechanical, chemical, and biological bodies.

\section{Inside the Enclosure: World as Camera}

Here we return to the hard-to-scrutinize photo album of Operation Greenhouse. Once we see the particular images it contains within a broader system of which they were and are an index, we can begin to appreciate the scale at which the nuclear testing regime enrolled sensing in support of imperial experiments. ${ }^{3}$ The album bears out this reliance on sensing even in the rough narratives and comparisons implied by the uncaptioned pages. Take, for example, a particularly wrenching sequence in which we move from one page depicting a cameraman loading film into a camera through two pages in which test workers load living dogs into special metal drums and install these drums on the test site (figures $\underline{6}, \mathbf{Z}$ ). In reading other technical reports from Operation Greenhouse, we learn that these specially outfitted drums secure live dogs against one side of the container, leaving a small portion of their skin ready to be exposed to the outside through an electrically shuttered aperture (Operation Greenhouse, Scientific Director's Report, Volume II, Part II-Evaluation of Program 2 1951, 33-34; Operation Greenhouse, Scientific Director's Report, Annex 2.7 Thermal-Radiation Injury 1951, 5). By placing a series of such drums at different distances from, and angles with respect to, the bomb blast, scientists could then study the effects of radiation on living tissue (figure 8). In depicting the loading of film into cameras and then the loading of dogs into drums, the album makes it clear that living organisms are just another form of film, sensors for the collection of data, or outputs. Report language makes clear not only the connection between these animal containers and

\footnotetext{
3 The photo album, of course, also evidences what Teaiwa (1999) called "militourism," and these images perform timeworn functions endemic to colonial representation. But the reason for the presence of cameras at this test was the same reason for the presence of all living creatures at this test-to collect information, and to help enroll ever more of the lifeworld as conduits of the same.
} 


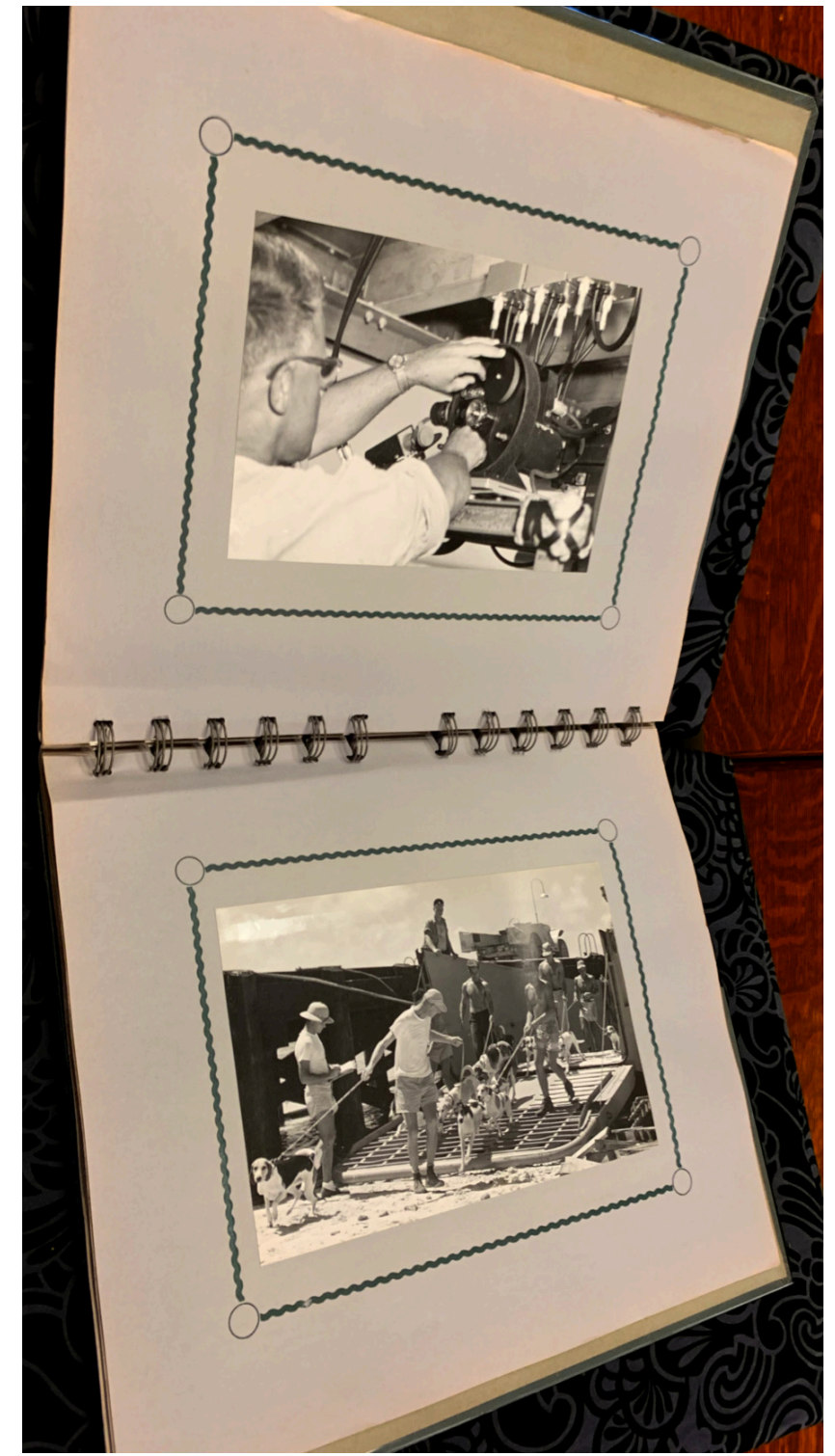

Figure 6: In facing pages of the Operation Greenhouse photo album, a photographer loads film into a camera (left), while workers unload dogs to be used as test subjects (right).

Image courtesy of the Rare Book \& Manuscript Library, University of Illinois at Urbana-Champaign.

cameras, recording data across exposure time, aperture size, and distance from the atomic light source, but also how these tests expand on data gathered from studying human victims of radiation in Japan (Operation Greenhouse, Scientific Director's Report, Annex 2.7 Thermal-Radiation Injury 1951, 4).

The beginning and the end of the lives of these creatures is of little consequence to the experiment's managers. Within the closed system of the test, the inputs and outputs are what count. "Dog 642" is either born on the island or shipped there by test managers; photographs of a lesion appear in a test report at 124 hours after exposure and again at 235 hours after exposure, "a Short Time before the Animal's Death" (Operation Greenhouse, Scientific Director's Report, Annex 2.7 Thermal-Radiation Injury 1951, 75). In this approach to life, we see an image of the whole operation. Enclosure of this creature serves 


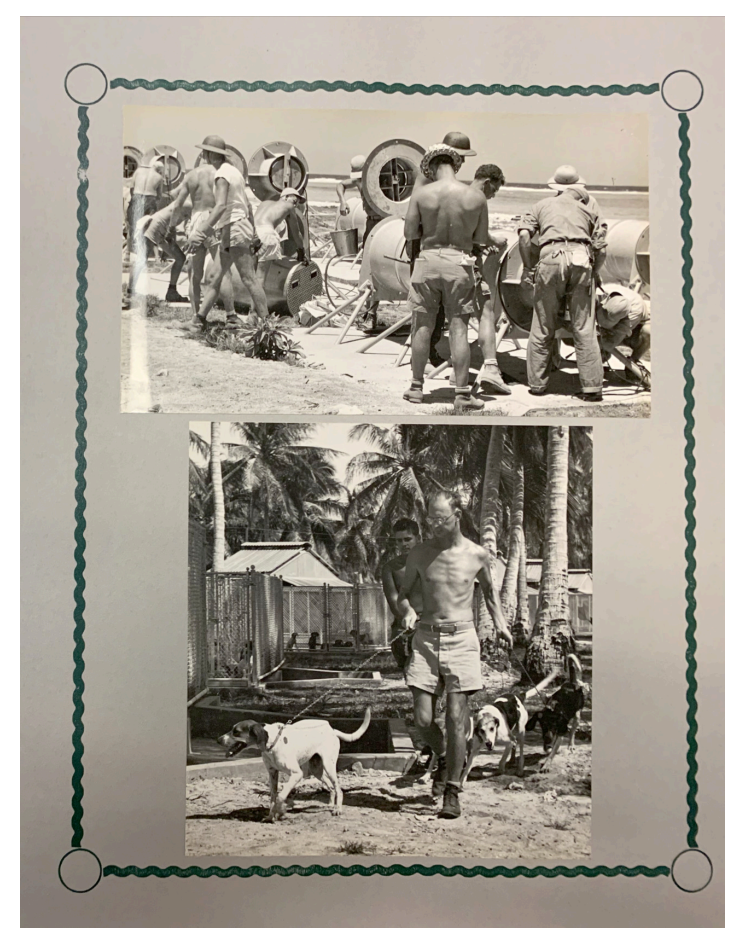

Figure 7: On the album's next page, workers load dogs into "exposure containers" (top) and bring new dogs from the temporary island kennel (bottom).

Image courtesy of the Rare Book \& Manuscript Library, University of Illinois at Urbana-Champaign.

TABLE 3.13 BURNS AS A FUNCTION OF DISTANCE AND ENERGY

Shot EAsY

\begin{tabular}{|c|c|c|c|c|c|c|c|c|c|}
\hline \multirow[t]{2}{*}{ STATION } & \multirow{2}{*}{$\begin{array}{c}\text { DISTANCE } \\
\text { FROM } \\
\text { BOMB } \\
\text { ZERO (yd) }\end{array}$} & \multicolumn{2}{|c|}{$\begin{array}{c}\text { TOTAL INTEGRATED THERMAL } \\
\text { ENERGY }\left(\mathrm{cal} / \mathrm{cm}^{2}\right)\end{array}$} & \multirow{2}{*}{$\begin{array}{l}\text { ANIMALS } \\
\text { OBSERVED }\end{array}$} & \multicolumn{5}{|c|}{$\begin{array}{c}\text { BURNS BEHIND UNMODIFIED } \\
\text { PORTS }\end{array}$} \\
\hline & & Calculated & Observed & & $4+$ & $3+$ & $2+$ & $1+$ & 0 \\
\hline 75 & 1,325 & 36 to 39 & $13.2 \pm 1.5$ & $\begin{array}{l}6 \text { pigs } \\
3 \text { dogs }\end{array}$ & $\begin{array}{l}6 \\
3 \\
\end{array}$ & & & & \\
\hline 76 & 2,270 & 10 to 13 & $6.2 \pm 0.5$ & $\begin{array}{l}4 \text { pigs } \\
3 \text { dogs }\end{array}$ & $\begin{array}{l}2 \\
1\end{array}$ & $\begin{array}{l}1 \\
2\end{array}$ & 1 & & \\
\hline 77 & 3,109 & 5.3 to 6.9 & $6.9 \pm 0.5$ & $\begin{array}{l}6 \text { pigs } \\
3 \text { dogs }\end{array}$ & 1 & 2 & $\begin{array}{l}3 \\
2\end{array}$ & 1 & \\
\hline 78 & 3,500 & 3.8 to 5.2 & $5.6 \pm 0.3$ & $\begin{array}{l}8 \text { pigs } \\
3 \text { dogs }\end{array}$ & & 1 & 2 & 6 & 2 \\
\hline $78 a$ & 4,508 & 2.2 to 3.1 & $3.6 \pm 0.3$ & $\begin{array}{l}6 \text { pigs } \\
0 \text { dogs }\end{array}$ & & & & & 6 \\
\hline 79 & 5,664 & 1.1 to 1.8 & $2.3 \pm 0.1$ & $\begin{array}{l}8 \text { pigs } \\
2 \text { dogs }\end{array}$ & & & & & $\begin{array}{l}8 \\
2\end{array}$ \\
\hline
\end{tabular}

Figure 8: A table from a test report displays the relative effects of exposure on animals placed at different distances from detonation during Operation Greenhouse (Operation Greenhouse, Scientific Director's Report, Annex 2.7 ThermalRadiation Injury 1951,27).

to enroll it within an information circuit. The test extracts from this dog what it puts in, through exposing it to radioactive particles that then register their presence to cameras and dosimeters. The animal itself is necessary only as a medium for the transmission of radiation and light, its body disposed of upon 
death. Likewise, the islands themselves, enclosed within an experimental gaze, serve as material and medium in the enactment of the imperial shutter, with the island's many resources never fully extracted or retained. In this sense, experimental imperialism treats all life as media-with disastrous consequences.

Given the totalizing force of this indiscriminate treatment of living beings as experimental media, the question of whether the Marshallese themselves received any better treatment must surely follow. And indeed, turning from the album's depictions of dog experiments, we find on the next pages pictures of the islanders in various states of exposed skin through traditional and Western dress. The military operation renders not only the atolls but also their people part of the closed experimental system. Skin was among its most important information media, with photography the lasting record. Dr. Robert A. Conrad, head of a Brookhaven National Laboratory medical team that would "examine" Marshallese annually for twenty-five years after the Operation Castle Bravo nuclear bombing of Bikini Atoll, on March 1, 1954, described in an account of his work the radiation burns on the skin of Marshallese and American sailors: ${ }^{4}$

In the late morning [after the Bravo detonation] the atmosphere became murky, and a snow-like, gritty material began falling from the sky; this continued for some hours, covering the ground and palm trees with a white coating, adhering to the skin and in the hair of the people, causing itching and burning of the skin and irritation of the eyes. Many children played in the ash; some of the children frolicked in the lagoon edge and thus, unknowingly, helped prevent or modify the development of radiation burns of the skin. The fallout settled on their food; some said the coconuts tasted bitter. (Conrad 1992, 8)

Conrad's chronicle is unusually ironic for a US government official. For example, he quotes an Atomic Energy Commission public statement made on March 11, some ten days after the Bravo experiment- "There were no burns. All were reported well" - and then proceeds to describe in the following pages of his report various radiation burns on Marshallese and on US soldiers. Human skin, he confesses, was the subject of American nuclear experimental violence, even if "accidental."

\footnotetext{
4 Operation Bravo was a thermonuclear test held at Bikini Atoll on March 1, 1954. Its yield was considerably higher than anticipated, and easterly winds carried fallout over the atolls of Rongelap, Ailingnae, and Utirik - inhabited by Marshallese who had been forcibly removed by American military from Bikini. According to Conrad (1992, 4), 239 Marshallese, 28 American servicemen, and 23 Japanese fishermen on the now infamous Lucky Dragon vessel "received significant exposure to radioactive fallout."
} 
Indeed, throughout his report, he stresses the "accidental" nature of the exposure of Marshallese people to nuclear fallout. Nevertheless, his is a chronicle of an official Atomic Energy Commission "research program" (1992, 24 ), one that he promotes as having positive repercussions for the science of fallout exposure:

This was the first time that a human population had been seriously exposed to radioactive fallout and the carefully documented findings have formed an important basis for action in other types of accidents involving radioactive fallout, the most notable being the recent reactor accident at Chernobyl in Russia. (1992, iv)

In the aftermath of the Bravo detonation, Conrad's team established a "control group" of non-exposed Marshallese so as to better understand the short-and long-term effects of fallout on the exposed group $(1992,25)$. They returned to the "population" annually for "examinations" that, he admits, were not designed for the "general health care of the Marshallese" but for tracing the effects of nuclear fallout $(1992,25)$. He thus stresses the great scientific value of the Bravo disaster, even though that value is ironically structured: "The contaminated environment of these islands provided tracer quantities of tagged elements, on a scale impossible to achieve in a planned experiment" (1992, 49). Experimental imperialism need not be intentional; it can be, like the camera shutter, aggressively opportunistic, seizing upon environmental "accidents" to construct a closed system as a way of emphasizing information gained over life lost. Indeed, the history of nuclear energy and weapons is rife with such examples; even at Chernobyl, as Kate Brown points out, nuclear radiation was present in Ukraine long before and long after the bracketed accident, in the form of other accidents as well as weapons testing (K. Brown 2019, 132-142).

So with the photo album of Operation Greenhouse: even without captions, we learn from these images how experimental imperialism works. It converts everything into either subject or sensor-everything, that is, except for the sovereign, the one who stands outside the system for whom its operations are executed. The experimental operation, just like the Operation Greenhouse album, implies the recognition of a sovereign viewer. The rest of us are left imagining the body of that phantom leader, whose synapses complete not only the album's representational work but also that of the nuclear test.

\section{Beyond Forensics: On Not Reconstructing (Failed) Empires}

As such, the task of storytelling in support of those displaced and irradiated by nuclear testing is more than one of "getting our facts straight," though we must not minimize the significance of facts. These facts are precisely what the Marshallese themselves-not to mention the downwinders, test workers, and uranium miners of the American West-have been mobilizing for decades now, demanding recompense. But justice will require something more, 
something like what Azoulay (2019) calls "unlearning imperialism.” How do we transcend the photographic, experimental, imperial regimes without negating their particular histories? Anthropocenic stories of imperialism's wastelands rely on sensational media to mischaracterize the affected people and places as foreclosed or disappeared. Unlearning imperialism will instead require attention to the forced enrollment of living beings as media themselves in disastrous systems. We must move from viewing disaster media solely as records of historical processes to asking what they reveal about deeper structural processes. For at these sites of historical and ongoing violence, historical imperial experimental structures are still very much at work - as are those who have been contesting and resisting their enrollment as media from the start.

Those of us not from Oceania need to continue to listen to the atolls and their inhabitants relating stories of the remains, the excesses that could not be enclosed. Narratives of disappearance and hope for evidence-based judgment of imperial crimes may both be part of this work, but on their own, they stand to reinscribe the structures of enclosure that made violence possible in the first place. Both rely on understandings of dispossession and expansion from which empire may have long moved on, or may have never employed in the first place. As Nicholas Brown asks in his engagement of the work of Glen Coulthard, Audra Simpson, and others, what happens "when we stop assuming that dispossession was successful and instead start from the conviction that settler colonialism is, in part, a failed project?" (N. A. Brown $2014,6)$. In his work on representations of melting glaciers, Brown invites us to modes of judgment that allow for the ongoing nature of violence even where dispossession, and even elimination of Indigenous peoples, did not succeed. Drawing from Aileen Moreton-Robinson's notion of "ontological belonging," Brown also highlights the inalienable and unceded relationships to land, people, and to time itself that native peoples steward as part of their ongoing participation in both political and symbolic resistance.

In the face of the challenges imperial experimentalism presents to recovering the past through media, we may well need whole other approaches to memory as well-a memory that mediates the present. "People are thought to walk forward into the past and walk backward into the future," Tongan scholar 'Okusitino Māhina (2010, 170) says, "both taking place in the present, where the past and the future are constantly mediated in the ever transforming present." What is the work of images in this temporality? Perhaps our forensic reconstructions are too frail, pressing, as they do, out onto a future in which the claims of the past can be adjudicated. Perhaps it is not then but now that demands our imagination, our unlearning. Perhaps we must learn to think the particulars that appear and reappear in our ever-transforming present-be it from the archives, the antique sales, the web, the soil and sand. Perhaps such thinking, such unlearning, such imagining, such seeing can wrest us from our general, imperial, experimental condition. 


\section{Authors' Note}

Thanks to fellow panelists Kate Chandler, Hillary Mushkin, and Abram Stern from the Visible Evidence conference where this paper emerged, and to the $M+E$ journal editors for inviting further development. We also want to recognize our debt to the peoples of the Bikini Atoll and the Marshall Islands, who through their activism, scholarship, and art continue to point to more lifegiving ways of seeing and being. May they see the full reparations they seek for the atrocities addressed in this article. 


\section{REFERENCES}

Arendt, Hannah. 1976. Origins of Totalitarianism. New York: Harcourt.

-_- 1982. Lectures on Kant's Political Philosophy. Chicago: University of Chicago Press. https://doi.org/10.7208/chicago/9780226231785.001.0001.

"Army Air Forces Operation Crossroads." 1946. Print. Rare Book and Manuscript Library, University of Illinois.

Ashby, W. Ross. 1962. "Principles of the Self-Organizing System.” In Principles of Self-Organization, edited by Heinz von Foerster and George W. Zopf, Jr., 255-78. London, UK: Pergamon Press.

Atkinson, Nathan S. 2011. "Newsreels as Domestic Propaganda: Visual Rhetoric at the Dawn of the Cold War." Rhetoric and Public Affairs 14 (1): 69-100. https://doi.org/10.1353/rap.2011.0003.

Azoulay, Ariella Aïsha. 2019. Potential History: Unlearning Imperialism. London: Verso Books.

Borges, Jorge Luis. 1999. “On Exactitude in Science.” In Collected Fictions, translated by Andrew Hurley, 325. New York: Penguin Books.

Bowker, Geoffrey C. 2005. Memory Practices in the Sciences. Cambridge, MA: MIT Press.

Brown, Kate. 2019. Manual for Survival: A Chernobyl Guide to the Future. New York, NY: Norton.

Brown, Nicholas Anthony. 2013. "Landscape, Justice, and the Politics of Indigeneity: Denaturalizing Structures of Settler Colonialism in the Alberta/Montana Borderlands.” PhD dissertation, University of Illinois, Urbana-Champaign.

- - . 2014. "The Logic of Settler Accumulation in a Landscape of Perpetual Vanishing." Settler Colonial Studies 4 (1): 1-26. https://doi.org/10.1080/2201473x.2013.784236.

Chow, Rey. 2006. The Age of the World Target. Durham, NC: Duke University Press.

Clarkson, P.W. 1954. "Reports on Evacuation of Natives and Surveys of Several Marshall Island Atolls,” April 9, 1954. Headquarters: Joint Task Force Seven. San Francisco. https://www.osti.gov/ opennet/servlets/purl/16130913-BF99J8/16130913.pdf.

Conrad, Robert A. 1992. "Fallout: The Experiences of a Medical Team in the Care of Marshallese Population Accidentally Exposed to Fallout Radiation.” Brookhaven National Laboratory, U.S. D.O.E. Upton, N.Y. https://doi.org/10.2172/10117645.

DeLoughrey, Elizabeth. 2009. "Radiation Ecologies and the Wars of Light." MFS Modern Fiction Studies 55 (3): 468-98.

- - . 2013. "The Myth of Isolates: Ecosystem Ecologies in the Nuclear Pacific." Cultural Geographies 20 (2): 167-84.

Edwards, Paul N. 2012. "Entangled Histories: Climate Science and Nuclear Weapons Research.” Bulletin of Atomic Scientists 68 (4): 28-40. https://doi.org/10.1177/0096340212451574.

Farbotko, Carol. 2010. "Wishful Sinking: Disappearing Islands, Climate Refugees and Cosmopolitan Experimentation.” Asia Pacific Viewpoint 51 (1): 47-60.

Friedman, Hal M. 1997. “'Races Undesirable from a Military Point of View’: United States Cultural Security in the Pacific Islands, 1945-1947.” The Journal of Pacific History 32 (1): 49-70. https://doi.org/10.1080/00223349708572827.

Hamilton, Kevin, and Ned O'Gorman. 2018. Lookout America! The Secret Hollywood Studio at the Heart of the Cold War. Hanover, NH: Dartmouth University Press.

Hariman, Robert, and John Lucaites. 2012. "The Iconic Image of the Mushroom Cloud and the Cold War Nuclear Optic.” In Picturing Atrocity: Photography in Crisis, edited by Geoffrey Batchen, Mick Gidley, Nancy K. Miller, and Jay Prosser, 135-46. London: Reaktion Books.

Harvey, David. 2004. “The 'New' Imperialism: Accumulation by Dispossession.” Socialist Register 40 (1): 63-87. 
“He’s Steady Under Fire.” 1945. Newsweek 26 (8): 31.

Higley, Melissa. Email to authors. 2020, February 7, 2020.

Lookout Mountain Laboratory. 1952. Operation Greenhouse. Film. https://www.lookoutamerica.org/ items/show $/ 5$.

Louis, William Roger. 1972. "Introduction.” In National Security and International Trusteeship in the Pacific, edited by William Roger Louis, xi-2. Annapolis, Maryland: Naval Institute Press.

Māhina, 'Okusitino. 2010. “Tā̀, Vā, and Moana: Temporality, Spatiality, and Indigeneity.” Pacific Studies 33 (2/3): 168-202.

Masco, Joseph. 2015. "The Age of Fallout." History of the Present: A Journal of Critical History 5 (2): 137-68. https://doi.org/10.5406/historypresent.5.2.0137.

Miller, William O., and Robert W. Thompson. 1972. "The Pacific Islands: Summary and Conclusions." In National Security and International Trusteeship in the Pacific, edited by William Roger Louis, 141-60. Annapolis, Maryland: Naval Institute Press.

O'Gorman, Ned. 2011. Spirits of the Cold War: Contesting Worldviews in the Classical Age of American Security Strategy. East Lansing, MI: Michigan State University Press.

Operation Greenhouse, Scientific Director's Report, Annex 2.7 Thermal-Radiation Injury. 1951. University of Rochester Atomic Energy Project.

Operation Greenhouse, Scientific Director's Report, Volume II, Part II-Evaluation of Program 2. 1951. University of Chicago \& Los Alamos Scientific Laboratory.

Rust, Susanne. 2019. "How the U.S. Betrayed the Marshall Islands, Kindling the Next Nuclear Disaster.” The Los Angeles Times, November 10, 2019. https://www.latimes.com/projects/ marshall-islands-nuclear-testing-sea-level-rise/.

Teaiwa, Teresia. 1999. "Reading Paul Gauguin's Noa Noa with Epeli Hau'ofa's Kisses in the Nederends: Militourism, Feminism, and the 'Polynesian' Body.” In Inside Out: Literature, Cultural Politics, and Identity in the New Pacific, edited by Vilsoni Hereniko and Rob Wilson, 249-63. Lanham, MD: Rowman \& Littlefield Publishers.

United Nations. 1945. Charter of the United Nations. https://www.un.org/en/sections/un-charter/ un-charter-full-text/.

Wedgwood, Camilla H. 1942. "Notes on the Marshall Islands." Oceania 13 (1): 1-23.

Wees, William C. 1993. Recycled Images: The Art and Politics of Found Footage Films. New York, NY: Anthology Film Archives.

Weisgall, Jonathan M. 1994. Operation Crossroads: The Atomic Tests at Bikini Atoll. Annapolis, MD: Naval Institute Press.

Wuerch, William L., and Dirk Anthony Ballendorf. 1994. Historical Dictionary of Guam and Micronesia. Metuchen, NJ: The Scarecrow Press.

Yusoff, Kathryn. 2018. A Billion Black Anthropocenes or None. Minneapolis, MN: University of Minnesota Press. https://doi.org/10.5749/9781452962054. 